\title{
A Study of Depression among Career Women
}

\author{
Mahvish Fatima $^{1 *}$, Rikza Parvez ${ }^{2}$
}

\section{ABSTRACT}

The present study is aimed to explore the level of depression among working and non working women. Sample of the study consisted of 28 working and 32 non-working married women who were recruited through purposive sampling technique. The working women were various post holders in different private and government organizations. Non-working women were only housewives/house makers. Beck Depression Inventory (BDI) was used to assess the level of their depression. Data was analyzed on SPSS 16. The result showed that non working women have more depression tendencies as compared to their working women counterparts.

Keywords: Depression, Career women and Non-Working Women, House makers

Clinical depression is a serious and pervasive mood disorder. It causes feelings of sadness, hopelessness, helplessness, and worthlessness. Depression can be mild to moderate with symptoms of apathy, little appetite, difficulty sleeping, low self-esteem, and low-grade fatigue, or it can be more severe Or it can be major depression with symptoms of depressed mood most of the day, diminished interest in daily activities, weight loss or gain, insomnia or hypersomnia (oversleeping), fatigue, feelings of guilt almost daily, and recurring thoughts of death or suicide. Depression is a serious condition that can impact every area of our life. It can affect our social life relationships, career, and sense of self-worth and purpose. It affects our mood, with feelings of sadness, emptiness, hopelessness and dysphoria. It affects the way we think, interfering with concentration and decision making. And, it affects our behavior, with increased irritability and loss of temper, social withdrawal, and a reduction in our desire to engage in pleasurable activities.

According to the WHO, Indians are among the world's most depressed. A study conducted by the global watchdogs found that while around 9\% of people in India reported having an extended period of depression within their lifetime, around 36\% suffered from what is called Major Depressive Episode (MDE). MDE is characterized by sadness, loss of interest or pleasure,

\footnotetext{
${ }^{1}$ Research Scholar, Department of Psychology, A.M.U Aligarh, India

${ }^{2}$ Assistant Professor, Department of Psychology, A.M.U Aligarh, India

*Responding Author

(C) 2016, M Fatima, R Parvez; licensee IJIP. This is an Open Access Research distributed under the terms of the Creative Commons Attribution License (http://creativecommons.org/licenses/by/2.0), which permits unrestricted use, distribution, and reproduction in any Medium, provided the original work is properly cited.
} 


\section{A Study of Depression among Career Women}

feelings of guilt or low self-worth, disturbed sleep or appetite, low energy and poor concentration besides feeling depressed. It is estimated that by the year 2020 if current trends for demographic and epidemiological transition continue, the burden of depression will increase to $5.7 \%$ of the total burden of disease and it would be the second leading cause of disability-adjusted life years (DALYs), second only to ischemic heart disease and by 2030 it is expected to be the largest contributor to disease burden.

In view of the morbidity, depression as a disorder has always been a focus of attention of researchers in India. Various authors have tried to study its prevalence, nosological issues, psychosocial risk factors including life events, symptomatology in the cultural context, comorbidity, psychoneurobiology, treatment, outcome, prevention, disability and burden.

Depression is more common in women than men. According to the National Mental Health Association, about one in every eight women will develop depression at some point during her lifetime. Not only are women more prone to depression than men, but the causes of female depression and even the pattern of symptoms are often different. Many factors contribute to the unique picture of depression in women-from reproductive hormones to social pressures to the female response to stress.

Although some of the signs and symptoms of depression are the same for both men and women, women tend to experience certain symptoms more often than men. For example, seasonal affective disorder-depression in the winter months due to lower levels of sunlight-is more common in women. Also, women are more likely to experience the symptoms of atypical depression. It has long been observed that women are about twice as likely to become clinically depressed (to have dysthmia or unipolar depression) as are men. These differences occur in most countries around the world. (Nolen - Hoeksemo and Girgus, 1994; Whilelm and Roy, 2003; Ge and Conger, 2003).

In atypical depression, rather than sleeping less, eating less, and losing weight, the opposite is seen: sleeping excessively, eating more (especially carbohydrates), and gaining weight. Feelings of guilt associated with depression are also more prevalent and pronounced in women. Women also have a higher incidence of thyroid problems. Since hypothyroidism can cause depression, this medical problem should always be ruled out by a physician in women who are depressed. Depression is becoming more common among middle aged female population and especially the factors associated are unique in this population. So this study was done to assess the burden of depression and its risk factors among adult female working and non-working population.

Women and depression is holding a relationship of much interest over the last two decades. As more and more women enter the work force, they are increasingly exposed not only of the same work environment as men, but also to unique pressure created by multiple roles and conflicting 


\section{A Study of Depression among Career Women}

expectations (Nelson and Burke 2000; Chang 2000). Modernity brought women education in its wake and she changed the arena of activity. She stepped out of the household of house and joined service like man. Now she got admiration, equality and opportunity.

The Role of women in the society is constantly questioned and for centuries women have struggled to find their place in a world that is predominantly male oriented. Women got the reputation of being housebound creatures through no fault of their own: they were repressed on every level. They were forced to wear certain dress codes, their education was severely curtailed and they were simply traded off in strategic marriages of convenience. The role specified to women in a society is a measuring bar and it is a true index of its civilization and cultural attainment. Fortunately times have changed, now days the women are not only restricted their involvement on domestic chores, procreation of children and their nurturing with family care and attention. A significant number of women are working and they are maintaining their dual roles of as employee and household keeper with financial assistance to their families. Having a job keeps a person busy, raises socioeconomic status and provides opportunities for self-fulfillment (Sieber 1974). On the other hand, some work characteristics can be sources of high strain job that can lead to mental health problems (Karasek \& Theorell 1990; Iacovides et al. 2003; Sieber 1974; Virtanen et al. 2007; Plaisier et al. 2007).

Overall, it has been noted that having a job has a positive effect on women's health, and that the increasing participation of women in the workforce over the last decades has not negatively affected their health but rather has improved it (Hall 1992). Working women are in better physical and psychological health than housewives (Hall 1992; Baruch \& Barnett 1986; Matthews et al. 2001), and have lower levels of morbidity and mortality than unemployed women and housewives (Silman 1987). When work conditions, demographic and family characteristics are taken into account, housewives show more depressive symptoms than working

married women (Lennon 1994). The purpose of present investigation was to find out the difference between working and non-working women as regards the level of depression and mental health.

\section{Objective of the Study}

The main objective of study was:

1. To measure the mental health between working and nonworking woman.

\section{Hypothesis of the Study}

2. There will be significant difference in depression among working and non-working woman. 


\section{METHOD}

\section{Participants}

For the purpose of the study a total of 60 women (28 working and 32 non-working) were randomly selected from different parts of Aligarh who were residents of new urban colonies, interestingly all of them were from Muslim families.

\section{Employment status}

Women were categorized into two groups:

Working women: women who were still working at time of interview

Housewives: women who had not had a paid job outside the home.

The purposive sampling procedure was used for collecting data. The study was an exploratory and cross sectional.

\section{Tool}

In the present study data was collected by administrating the Beck Depression Inventory.

The Beck Depression Inventory (BDI) is a 21-item, self-report rating inventory that measures characteristic attitudes and symptoms of depression (Beck, et al., 1961). The BDI takes approximately 10 minutes to complete. Internal consistency for the BDI ranges from .73 to .92 with a mean of .86. (Beck, Steer, \& Garbin, 1988). The BDI demonstrates high internal consistency, with alpha coefficients of .86 and .81 for psychiatric and non-psychiatric populations respectively (Beck et al., 1988).

\section{RESULT}

Result shows the different levels of depression between both the groups.

Table 1: Showing The Means, Standard Deviations, And t-Values Of Working And NonWorking

Women With Respect To the Variable - Depression.

\begin{tabular}{|l|l|l|l|l|l|}
\hline Work & $\mathbf{N}$ & Mean & Std. Deviation & t & P \\
\cline { 1 - 4 } Working & 28 & 19.8571 & 2.15534 & 10.183 & .000 \\
\hline Housewife & 32 & 31.1875 & 5.52669 & & \\
\hline
\end{tabular}

As it is clear from table that means cores of non-working women $(\mathrm{M}=31.1875)$ is much higher than mean scores of working women $(\mathrm{M}=19.8571)$, and $\mathrm{t}$ - value $(\mathrm{t}=10.183, \mathrm{p}>.01)$ showed the significant difference between the two groups.

\section{DISCUSSION}

The study analyzed the depression levels of working and non- working women. The overall obtained results showed that some significant differences were observed between the selected 


\section{A Study of Depression among Career Women}

variable (Depression). Non-Working women showed higher level of depression than their counterparts (31.1875>19.8571).

Findings of the study were that the houses hold average income of the housewives was more than that of working women but still the level of depression was much higher in the housewives. The housewives were found to have more average number of children as compare to working women. Having more average number of children was one of the causes of depression among housewives because they have the burden of handling more babies alone. The housewives were less educated as compare to working women which was another reason for being depressed because education gives vision and better understanding of life. There was significant difference in the level of depression of working women and housewives. The level of depression among the housewives was more than that of working women.

The finding might be ascribed to the fact that working women are generally involved in many works simultaneously and they had some time for making friends and enjoy leisure time (Rapaport \& Rapaport,1972), yet the feeling of getting bored was less experienced by working women than non-working ones.

\section{Acknowledgments}

The author appreciates all those who participated in the study and helped to facilitate the research process.

\section{Conflict of Interests}

The author declared no conflict of interests.

\section{REFERENCES}

American Psychiatric Association. (1980). Diagnostic and Statistical Manual. Third edition. Washington DC: American Psychiatric Association.

American Psychiatric Association. (1987). Diagnostic and Statistical Manual. Third edition revised. Washington DC: American Psychiatric Association.

Arieti, S. (1974). Anxiety anxilated states. American handbook of Psychiatrist. The foundations of psychiatry, (Vol. 1, 2nd ed, basic books) Inc. Publishers: New York.

Barnett, G. C., \& Baruch, O. K. (1985). Women's involvement in multiple roles, role strain, and psychological distress. Journal of Personality and Social Psychology, 49, 135-145.

Baruch, G., Barnett, R., \& Rivers, C. (1985). Life prints: New patterns of love and work for today's women. New York: Signet Books.

Beck, A. T., Steer, R.A., \& Garbin, M.G. (1988). Psychometric properties of the Beck Depression Inventory: Twenty-five years of evaluation.Clinical Psychology Review, 8(1), 77-100. 


\section{A Study of Depression among Career Women}

Beck, A.T., Ward, C. H., Mendelson, M., Mock, J., \& Erbaugh, J. (1961). An inventory for measuring depression. Archives of General Psychiatry, 4, 561-571.

Beck, A.T., Ward, C.H., Mendelson, M., Mock, J.E. \& Erbaugh, J.K. (1961). Arch Inventory for measuring Depression. Archives of General Psychiatry, .4, 561-571.

Bernard, J. (1971 ). Women and the public interest- An Essay on Politics \& Protest. Chicago : Aidile.

Depression in Special Situations. Retrieved on 26-4-2016, from -

http://www.dnaindia.com/india/report-indians-most-depressed-people-in-the-world-sayswho-study-1570027

Hall , E.M. (1992). Double exposure: the combined impact of the home and work environments of psychosomatic strain in Swedish women and men. International Journal of Health Services, 22(2), 239-260.

Iacovides, K.N; Fountoulakis, S; Kaprinis, S; \& Kaprinis, G. (2003) The relationship between job stress, burnout and clinical depression . Journal of Affective Disorders, 75, 209-221.

Kapur, R. L. \& Carstairs ,G. M. (1974). Indian psychiatric survey schedule. Social Psychiatry, 9, 71-76.

Karasek, R; \& Theorell, T. (1990). Healthy work: stress, productivity, and the reconstruction of working life. New York: Basic Books.

Lennon, M.C. \& Rosenfield, S. (1992). Women and Mental Health: The Interaction of Job and Family Conditions. Journal of Health and Social Behavior, 33(3), 16-27.

Lennon, M.C. (1994).Women, work, and well-being: the importance of work conditions. Journal of Health and Social Behavior,35(3), 235-247.

Matthews, S., Power, C., \& Stansfeld, S. A.(2001). Psychological distress and work and home roles: a focus on socio-economic differences in distress. Psychological Medicine, 31(4), 725-736.

Nelson, D. L. \& Bruke, R. J. (2000). Women executive health, stress and success. The Academy of Management Executive, 14, 107-21.

Nolen-Hoeksema, S.,\& Girgus, J.S. (1994).The emergence of gender differences in depression during adolescence. Psychological Bulletin, 115,424-443.

Plaisier, I., De Bruijn ,J.G., De Graaf, R., Ten Have, M., Beekman, A.T., \& Penninx ,B.W.(2007). The contribution of working conditions and social support to the onset of depressive and anxiety disorders among male and female employees. Social Science Medicine, 64(2), 401-410.

Sieber, S. D. (1974). Toward a theory of role accumulation. American Sociological Review, 39(4), 567-578.

Silman , A. J. (1987). Why do women live longer and is it worth it? British Medicine Journal, 294(6583), 1311-1312.

Singh, G. (1979). Depression in India - a cross-cultural perspective. Indian Journal of Psychiatry, 21, 235-239. 


\section{A Study of Depression among Career Women}

Virtanen, M., Honkonen, T., Kivimaki, M., Ahola ,K., Vahtera, J., Aromaa ,A., \& Lonnqvist J. (2007).Work stress, mental health and antidepressant medication findings from the Health 2000 Study. Journal of Affective Disorder, 98(3), 189-197.

World Health Organization. (1974.) International Classification of Diseases (8th revision), Geneva: W.H.O.

World Health Organization. (1978.) International Classification of Diseases (9th revision), Geneva: W.H.O.

How to cite this article: M Fatima, R Parvez (2016), A Study of Depression among Career Women, International Journal of Indian Psychology, Volume 3, Issue 4, No. 67, ISSN:23485396 (e), ISSN:2349-3429 (p), DIP:18.01.183/20160304, ISBN:978-1-365-39397-6 